\title{
Risk of cancer among paper recycling workers
}

\author{
Bo Andreassen Rix, Ebbe Villadsen, Gerda Engholm, Elsebeth Lynge
}

The Danish Cancer Society, Copenhagen, Denmark

B A Rix

E Villadsen

G Engholm

E Lynge

Correspondence to:

Dr Bo Andreassen Rix, Danish Cancer Society, Strandboulevarden 49 , DK-2100 Copenhagen, Denmark.

\begin{abstract}
Objectives-Studies in traditional paper mills have indicated an excess cancer risk, and mutagenic compounds have been identified in the industry. No studies have reported on risk of cancer in paper recycling. Therefore the cancer incidence in Danish paper recycling mills was investigated.

Methods-5377 employees in five paper recycling plants were included in a historical cohort study. The workers had been employed in paper recycling in 196590 , and the cohort was followed up until 31 December 1993. The expected number of cancer cases was calculated from national rates.

Results-There was significantly more pharyngeal cancer among male workers (seven observed (standardised incidence ratio (SIR) 3.33, 95\% confidence interval (95\% CI) 1.34 to 6.87$)$ ). There was slightly more lung cancer among male workers in production (39 observed, SIR 1.21, 95\% CI 0.86 to 1.65). Risk of Hodgkin's disease was doubled in male production worker (four observed, SIR 1.90, 95\% CI 0.51 to 4.85 ).

Conclusions-The increased risk of pharyngeal cancer found in this study is interesting but may be influenced by confounders such as smoking and alcohol intake. This study also indicates an excess risk of Hodgkin's disease, which is in accordance with some studies in the traditional paper mills. As this is the first report on risk of cancer in paper recycling, further studies are needed.
\end{abstract}

(Occup Environ Med 1997;54:729-733)

Keywords: neoplasms; occupational exposure; paper industry

Many chemical compounds are used in the pulp and paper industry, and some of the compounds have been shown to be mutagenic.' In effluent water and sludge from paper mills, 2 ,

lymphomas, ${ }^{6}$ but no study has previously been undertaken to investigate the risk of cancer in the paper recycling industry. De-inking and recycling of paper will become an important industry in the future as paper consumption increases. ${ }^{7}$ As Denmark has an old paper recycling industry ${ }^{8}$ and a national compulsory cancer registration, we conducted a historical cohort study of incidence of cancer in Danish paper recycling plants.

\section{Materials and methods}

DESCRIPTION OF THE PAPER RECYCLING PLANTS Five Danish paper recycling plants were included. The oldest plant started production in 1956 and the newest in 1969. In three plants, paper waste was mixed with water, and slimicides, sizing agents, flocking chemicals, fillers, and other chemicals were added to the paper stock.

Two plants used a de-inking process to remove printing ink from newspapers and magazines. In a flotation de-inking system, paper waste was dissolved in water, fatty acids and other compounds were added, and printing ink and impurities were separated by an air flow in a foam separator.

The most common chemicals used in the Danish repulping and de-inking industry were fatty acid derivatives, hydrogen peroxide, sodium bisulphite, sodium hydroxide, sodium silicate, sodium dithionite, aluminum sulphate, chlorine, hypochlorite, polyethylenimine, (diethylenetrinitrilo)penta-acetic acid, bentonite, kaolin, resins, and acrylamide polymers. Several slimicides - for example, thiazole compounds, bromine compounds, and copper compounds-were also used. Industrial hygiene measurements in the paper recycling industry in Denmark showed that dust concentrations in the industry may have exceeded 5 $\mathrm{mg} / \mathrm{m}^{3}$, and micro-organisms and endotoxins were often measured in the work environment. ${ }^{9}$ Repulping and de-inking took place in open ponds, but from the mid-1970s workers spent part of the working hours in closed control rooms. 3, 7, 8-tetrachlorodibenzo-p-dioxin (2,3,7,8TCDD), other dioxins, and polychlorinated dibenzofurans (PCDFs) have been found. ${ }^{2-4}$ Studies of polychlorinated dibenzodioxins (PCDDs) and PCDFs in paper products have shown the highest concentrations in pulp from recycled paper, ${ }^{4}$ and a high incidence of chromosomal mutations was found in ferns in a river contaminated by paper recycling effluent. $^{5}$

Studies of workers from the pulp and paper industry have indicated an increased risk of lung cancer, stomach cancer, and malignant

\section{REGISTRATION OF THE PAPER RECYCLING}

INDUSTRY COHORT

No historical archive on former employees was available at four of the five plants included. The registration was therefore based on company records of active workers and data from a national supplementary pension scheme called ATP. This was started on 1 April 1964, and is based on compulsory quarterly contributions from employees and employers. Information on contributions and periods of employment are stored in a data bank together with names, 
dates of birth, personal identification numbers of employees, and unique identification numbers of employers. Data on all people employed in the plants from 1 April 1964 until 31 December 1990 were retrieved. As some former employees were missing in the early period of the pension scheme in 1964, only people employed on 1 January 1965 or later were included. Lists of former employees were sent to the plant managers for further information on job titles and departments. This information was supplemented from various sources, and for most former employees it was possible to find if they had been in production, maintenance and storage, or administration.

In plant No 5, 254 active and former workers were registered in the plant files. From the ATP supplementary pension scheme, 184 additional workers were retrieved. Data concerning these people were sent to the company and to retired foremen for completion of information about job titles and departments. Only 376 workers employed from 1 January 1970 were included in the final cohort, as production was changed to paper recycling from that date.

A total of 5379 people were registered in the Danish paper recycling industry cohort (table 1).

\section{FOLLOW UP OF THE COHORT}

From 1 April 1968, all Danish citizens have been given a unique personal identification number and all dates of deaths, emigrations, and disappearances have been recorded in the central population register. People with a personal identification number were searched for in the Central Population Register for vital status. People without a personal identification number were searched for in the national mortality registry for date of death. A total of 5377 people out of 5379 in the cohort were identified. Two were excluded from the analysis (table 1). For each person, person-years at risk were calculated from the registered start of employment, until death, emigration, disappearance, or end of follow up on 31 December 1993, whichever came first.

The Danish cancer register started in 1943. Members of the Danish paper recycling cohort without a personal identification number were searched for manually on lists of cancer patients with equivalent sex and date of birth in the cancer register. Members with a personal identification number were searched for in the cancer register on 1 June 1996.

All tumours diagnosed in the individual risk periods were included. The expected number of cancer cases were calculated from personyears at risk and the cancer incidences for the total Danish population for sex, five-year age groups, and calendar periods (1963-67, 1968$72, \ldots 1988-92$ ) with the PYRS program. ${ }^{10}$

A standardised incidence ratio (SIR) was calculated by dividing the observed number of cancer cases in a given group by the expected number, and a $95 \%$ confidence interval $(95 \%$ CI) was calculated. ${ }^{11}$

Cancer sites of specific interest were analysed with Poisson regression models. Duration of employment, years since first employment, and year of first employment were used as the independent factors, and the $\log$ of the expected number of cases based on population rates was used as an offset variable. " The modelling was done with the statistical package Epicure. $^{12}$

\section{Results}

Among men, the overall incidence of cancer was significantly lower than expected (206 observed cases, SIR $0.85,95 \%$ CI 0.73 to 0.97 , table 2). The risk of pharyngeal cancer was increased more than threefold (seven observed, 2.10 expected, SIR $3.33,95 \%$ CI 1.34 to 6.87 ). The risk of lung cancer was marginally in excess ( 47 observed, SIR $1.11,95 \%$ CI 0.81 to 1.47), and an excess of Hodgkin's disease was indicated (four observed cases, 2.57 expected, SIR $1.56,95 \%$ CI 0.42 to 3.98 ).

When analysed by latency time and duration of employment (table 3), no clear trend was seen for the overall risk of cancer. The risk of lung cancer was higher than expected for short time workers and workers with at least 10 years of employment. The risk of Hodgkin's disease increased with duration of employment, based on very few cases (table 3 ).

In the Poisson analysis, the risk of lung cancer increased with time since first employment (relative risk (RR) $1.28,95 \%$ CI 0.58 to 2.82 for 10-19 years of latency, RR $1.80,95 \%$ CI 0.73 to 4.43 for $20-24$ years of latency, and $R R$ $3.23,95 \%$ CI 1.28 to 8.13 for a latency of $\geqslant 25$ years, $\mathrm{P}$ for trend 0.07 , compared with $<10$ years of latency). If the analysis was restricted to men employed for more than one year, the trend was stronger with RR 3.79, 95\% CI 1.24 to 11.60 for $\geqslant 25$ years of latency, $P$ for trend 0.04 .

The risk of pharyngeal cancer among men working in production of recycled paper was significantly in excess (five observed, 1.45 expected, SIR $3.45,95 \%$ CI 1.11 to 8.05 ),

Table 1 Number of people* and person-years in the Danish paper recycling plant study

\begin{tabular}{|c|c|c|c|c|c|c|c|c|c|c|c|c|}
\hline \multirow[b]{2}{*}{$\begin{array}{l}\text { Plant } \\
\text { No }\end{array}$} & \multicolumn{4}{|l|}{ Men } & \multicolumn{4}{|l|}{ Women } & \multicolumn{4}{|l|}{ Total } \\
\hline & $\begin{array}{l}\text { Registered } \\
\text { people } \\
\text { (n) }\end{array}$ & Untraced & $\begin{array}{l}\text { Included } \\
\text { in } \\
\text { cohort }\end{array}$ & $\begin{array}{l}\text { Person- } \\
\text { years }\end{array}$ & $\begin{array}{l}\text { Registered } \\
\text { people } \\
\text { (n) }\end{array}$ & Untraced & $\begin{array}{l}\text { Included } \\
\text { in } \\
\text { cohort }\end{array}$ & $\begin{array}{l}\text { Person- } \\
\text { years }\end{array}$ & $\begin{array}{l}\text { Registered } \\
\text { people } \\
\text { (n) }\end{array}$ & Untraced & $\begin{array}{l}\text { Included } \\
\text { in } \\
\text { cohort }\end{array}$ & $\begin{array}{l}\text { Person- } \\
\text { years }\end{array}$ \\
\hline 1 & 629 & 1 & 628 & 11223 & 119 & 0 & 119 & 1342 & 748 & 1 & 747 & 12565 \\
\hline 2 & 3000 & 0 & 3000 & 44926 & 734 & 0 & 734 & 8646 & 3734 & 0 & 3734 & 53572 \\
\hline 3 & 344 & 0 & 344 & 4684 & 26 & 0 & 26 & 272 & 370 & 0 & 370 & 4956 \\
\hline 4 & 142 & 1 & 141 & 1162 & 9 & 0 & 9 & 76 & 151 & 1 & 150 & 1238 \\
\hline 5 & 337 & 0 & 337 & 5108 & 39 & 0 & 39 & 533 & 376 & 0 & 376 & 5641 \\
\hline Total & 4452 & 2 & 4450 & 67103 & 927 & 0 & 927 & 10869 & 5379 & 2 & 5377 & 77972 \\
\hline
\end{tabular}

* Seven people employed in two plants were registered in the plant of first employment. 
Table 2 Observed $(O)$ and expected (E) number of cancer cases among employees in the Danish paper recycling industry by diagnostic group

\begin{tabular}{|c|c|c|c|c|c|c|c|c|c|}
\hline \multirow{2}{*}{$\begin{array}{l}\text { Diagnosis } \\
\text { ICD-7 }\end{array}$} & \multirow[b]{2}{*}{ Site } & \multicolumn{4}{|l|}{ Men } & \multicolumn{4}{|c|}{ Women } \\
\hline & & $O$ & $E$ & $S I R$ & $(95 \% C I)$ & $O$ & $E$ & SIR & $(95 \% C I)$ \\
\hline 104-205 & All cancer & 206 & 243.59 & 0.85 & (0.73 to 0.97$)$ & 39 & 36.62 & 1.06 & (0.76 to 1.46$)$ \\
\hline $140-144$ & Buccal cavity & 5 & 5.76 & 0.87 & (0.28 to 2.03 ) & - & 0.29 & - & - \\
\hline $145-148$ & Pharynx & 7 & 2.10 & 3.33 & (1.34 to 6.87$)$ & - & 0.11 & - & - \\
\hline 150 & Oesophagus & 1 & 3.06 & 0.33 & (0.00 to 1.82$)$ & - & 0.13 & - & - \\
\hline 151 & Stomach & 8 & 8.60 & 0.93 & (0.40 to 1.83$)$ & - & 0.58 & - & - \\
\hline 153 & Colon & 12 & 15.34 & 0.78 & (0.40 to 1.37$)$ & 5 & 2.18 & 2.29 & (0.74 to 5.35$)$ \\
\hline 154 & Rectum & 6 & 11.58 & 0.52 & (0.19 to 1.13$)$ & 1 & 1.04 & 0.96 & $(0.01$ to 5.35$)$ \\
\hline 155 & Liver, primary & 2 & 2.43 & 0.82 & (0.09 to 2.97 ) & - & 0.20 & - & - \\
\hline 155.1 & Gall bladder & 1 & 1.37 & 0.73 & (0.01 to 4.06$)$ & - & 0.27 & - & - \\
\hline 157 & Pancreas & 8 & 6.44 & 1.24 & (0.53 to 2.45 ) & - & 0.69 & - & - \\
\hline 161 & Larynx & 3 & 4.44 & 0.68 & (0.14 to 1.97$)$ & - & 0.14 & - & - \\
\hline 162 & Lung & 47 & 42.52 & 1.11 & (0.81 to 1.47 ) & 4 & 2.63 & 1.52 & (0.41 to 3.89 ) \\
\hline 170 & Breast & 1 & 0.38 & 2.63 & $(0.03$ to 14.64$)$ & 9 & 9.42 & 0.96 & (0.44 to 1.81$)$ \\
\hline 171 & Cervix uteri & - & - & - & - & 2 & 2.75 & 0.73 & (0.08 to 2.63 ) \\
\hline 172 & Corpus uteri & - & - & - & - & 1 & 1.85 & 0.54 & (0.01 to 3.01$)$ \\
\hline 175 & Ovary & - & - & - & - & 1 & 1.93 & 0.52 & (0.01 to 2.88 ) \\
\hline 177 & Prostate & 14 & 18.35 & 0.76 & $(0.42$ to 1.28$)$ & - & - & - & - \\
\hline 178 & Testis & 7 & 9.57 & 0.73 & $(0.29$ to 1.51$)$ & - & - & - & - \\
\hline 180 & Kidney & 7 & 7.73 & 0.91 & (0.36 to 1.87$)$ & 2 & 0.69 & 2.90 & (0.33 to 10.47$)$ \\
\hline 181 & Bladder & 14 & 19.99 & 0.70 & ( 0.38 to 1.18$)$ & 2 & 0.79 & 2.53 & $(0.28$ to 9.14$)$ \\
\hline 190 & Melanoma of skin & 7 & 7.05 & 0.99 & (0.40 to 2.05$)$ & - & 1.53 & - & - \\
\hline 191 & Skin, other & 25 & 34.56 & 0.72 & (0.47 to 1.07$)$ & 6 & 4.22 & 1.42 & (0.52 to 3.09$)$ \\
\hline 193 & Brain & 8 & 9.06 & 0.88 & (0.38 to 1.74$)$ & 2 & 1.28 & 1.56 & $(0.18$ to 5.64$)$ \\
\hline 196 & Bone & - & 0.55 & - & - & - & 0.04 & - & - \\
\hline 197 & Connective tissue & 2 & 1.16 & 1.72 & $(0.19$ to 6.22$)$ & - & 0.12 & - & - \\
\hline 200,202 & $\begin{array}{l}\text { Non-Hodgkin's } \\
\text { lymphoma }\end{array}$ & 5 & 6.39 & 0.78 & (0.25 to 1.83$)$ & - & 0.67 & - & - \\
\hline 201 & Hodgkin's disease & 4 & 2.57 & 1.56 & $(0.42$ to 3.98$)$ & - & 0.26 & - & - \\
\hline 204 & Leukaemia & 1 & 6.55 & 0.15 & (0.00 to 0.85$)$ & 1 & 0.60 & 1.67 & (0.02 to 9.27$)$ \\
\hline
\end{tabular}

whereas the risk of lung cancer was moderately increased (39 observed, SIR 1.21, 95\% CI 0.86 to 1.65) (table 4). The risk of Hodgkin's disease was doubled, based on four cases ( SIR $1.90,95 \%$ CI 0.51 to 4.85 ).

Among women, the overall risk of cancer was close to the expected (39 observed, SIR 1.06, $95 \%$ CI 0.76 to 1.46 ) (table 2). The risk of colon cancer was doubled based on five observed cases (SIR 2.29, 95\% CI 0.74 to 5.35), and the risk of lung cancer was increased (four observed, SIR $1.52,95 \%$ CI 0.41 to 3.89 ) (table 2).

\section{Discussion}

The overall risk of cancer was lower than expected among men and close to that expected among women in the Danish cohort of paper recycling workers, and this is in accordance with cohort studies in the traditional pulp and paper industry. ${ }^{13-16} \mathrm{~A}$ healthy worker effect may explain the low overall cancer incidence in men. As the industry is new, the average follow up period was only 14.5 years.

Pharyngeal cancer was significantly in excess in this Danish paper recycling cohort. Pharyngeal cancer is related to smoking and alcohol consumption. ${ }^{17} 18$ Alcohol was normally not allowed at the plants, but smoking was allowed in special rooms. In a Danish health survey study in 1972, ${ }^{19}$ smoking and alcohol consumption among male paper workers did not differ much from that of other workers, but confounding by these factors cannot be ruled out. However, confounding by smoking may not alone explain a threefold excess risk of pharyngeal cancer. ${ }^{20}$ Risk of cancer of the buccal cavity and pharynx combined was increased in some proportionate mortality studies among pulp and paper workers, ${ }^{21}{ }^{22}$ but cohort studies have shown the combined risk of buccal cavity and pharyngeal cancer to be close to or lower than expected. ${ }^{13-16}$

This study suggested that the incidence of lung cancer was slightly increased among men in production and moderately increased in short term workers with less than one year of employment. Occupational exposures may be high in this subgroup, as members may have occupied the least qualified jobs. Other explanations such as smoking in a more marginalised group of workers may also be relevant. ${ }^{23}$ For male employees with at least one year of employment, the study indicated an increasing

Table 3 Observed $(O)$ cancer incidence for all malignant neoplasms, pharyngeal cancer, lung cancer, and Hodgkin's disease among men by latency and by duration of employment in Danish paper recycling plants

\begin{tabular}{|c|c|c|c|c|c|c|c|c|c|c|c|c|}
\hline & \multicolumn{3}{|c|}{ All cancers } & \multicolumn{3}{|c|}{ Pharyngeal cancer } & \multicolumn{3}{|c|}{ Lung cancer } & \multicolumn{3}{|c|}{ Hodgkin's disease } \\
\hline & $O$ & SIR & $(95 \% C I)$ & $O$ & $S I R$ & $(95 \% C I)$ & $O$ & $S I R$ & $(95 \% C I)$ & $O$ & $S I R$ & $(95 \% C I)$ \\
\hline \multicolumn{13}{|c|}{ Years since first employment $(y)$ : } \\
\hline $0-9$ & 58 & 0.80 & (0.61 to 1.03$)$ & 3 & 4.76 & (0.96 to 13.91$)$ & 9 & 0.76 & (0.35 to 1.44$)$ & 3 & 2.01 & (0.40 to 5.88$)$ \\
\hline $10-19$ & 91 & 0.84 & (0.68 to 1.03$)$ & 3 & 3.13 & $(0.63$ to 9.13$)$ & 19 & 0.97 & (0.58 to 1.51$)$ & 1 & 1.19 & $(0.02$ to 6.62$)$ \\
\hline$\geqslant 20$ & 57 & 0.91 & (0.69 to 1.18$)$ & 1 & 1.96 & $(0.03$ to 10.91$)$ & 19 & 1.72 & (1.04 to 2.69 ) & 0 & - & - \\
\hline \multicolumn{13}{|c|}{ Duration of employment $(y)$ : } \\
\hline$<1$ & 55 & 0.85 & (0.64 to 1.10$)$ & 3 & 5.00 & $(1.00$ to 14.61$)$ & 14 & 1.42 & (0.78 to 2.39$)$ & 1 & 0.89 & (0.01 to 4.97$)$ \\
\hline $1-9$ & 96 & 0.83 & $(0.67$ to 1.02$)$ & 4 & 4.17 & (1.12 to 10.67$)$ & 15 & 0.73 & (0.41 to 1.21 ) & 2 & 1.75 & $(0.20$ to 6.33$)$ \\
\hline $10-19$ & 44 & 0.82 & $(0.60$ to 1.10$)$ & 0 & - & - & 14 & 1.36 & (0.74 to 2.28$)$ & 1 & 3.85 & (0.05 to 21.40$)$ \\
\hline$\geqslant 20$ & 11 & 1.13 & (0.56 to 2.03$)$ & 0 & 一 & - & 4 & 2.13 & (0.57 to 5.45$)$ & 0 & - & - \\
\hline
\end{tabular}


Table 4 Observed (O) and expected (E) number of cancer cases among male workers in the Danish paper recycling industry by diagnostic group and work process*

\begin{tabular}{|c|c|c|c|c|c|c|c|c|c|}
\hline \multirow{2}{*}{$\begin{array}{l}\text { Diagnosis } \\
\text { ICD-7 }\end{array}$} & \multirow[b]{2}{*}{ Site } & \multicolumn{4}{|c|}{ Recycled pulp and paper production } & \multicolumn{4}{|c|}{ Maintenance and storage } \\
\hline & & $O$ & $E$ & $S I R$ & $(95 \% C I)$ & $O$ & $E$ & $S I R$ & $(95 \% C I)$ \\
\hline $104-205$ & All cancer & 169 & 186.93 & 0.90 & (0.77 to 1.05$)$ & 34 & 43.09 & 0.79 & $(0.55$ to 1.10$)$ \\
\hline $140-144$ & Buccal cavity & 5 & 4.43 & 1.13 & (0.36 to 2.63$)$ & - & 1.00 & - & - \\
\hline $145-148$ & Pharynx & 5 & 1.45 & 3.45 & (1.11 to 8.05$)$ & 1 & 0.33 & 3.03 & (0.04 to 16.86$)$ \\
\hline 150 & Oesophagus & 1 & 2.34 & 0.43 & (0.01 to 2.38$)$ & - & 0.55 & - & - \\
\hline 151 & Stomach & 7 & 6.47 & 1.08 & (0.43 to 2.23$)$ & 1 & 1.58 & 0.63 & (0.01 to 3.52$)$ \\
\hline 153 & Colon & 9 & 11.59 & 0.78 & (0.35 to 1.47$)$ & 2 & 2.81 & 0.71 & (0.08 to 2.57$)$ \\
\hline 154 & Rectum & 6 & 8.76 & 0.68 & (0.25 to 1.49$)$ & - & 2.11 & - & - \\
\hline 155 & Liver, primary & 2 & 1.84 & 1.09 & (0.12 to 3.92$)$ & - & 0.44 & - & - \\
\hline 155.1 & Gall bladder & 1 & 1.03 & 0.97 & $(0.01$ to 5.40$)$ & - & 0.26 & - & - \\
\hline 157 & Pancreas & 7 & 4.86 & 1.44 & (0.58 to 2.97$)$ & 2 & 1.17 & 1.71 & $(0.19$ to 6.17$)$ \\
\hline 161 & Larynx & 2 & 3.41 & 0.59 & (0.07 to 2.12$)$ & - & 0.78 & - & - \\
\hline 162 & Lung & 39 & 32.23 & 1.21 & (0.86 to 1.65$)$ & 9 & 7.75 & 1.16 & (0.53 to 2.20$)$ \\
\hline 177 & Prostate & 11 & 13.38 & 0.82 & (0.41 to 1.47$)$ & 2 & 3.57 & 0.56 & (0.06 to 2.02$)$ \\
\hline 178 & Testis & 6 & 8.11 & 0.74 & $(0.27$ to 1.61$)$ & 1 & 1.23 & 0.81 & $(0.01$ to 4.52$)$ \\
\hline 180 & Kidney & 7 & 5.91 & 1.18 & (0.47 to 2.44$)$ & - & 1.37 & - & - \\
\hline 181 & Bladder & 10 & 15.16 & 0.66 & (0.32 to 1.21$)$ & 5 & 3.62 & 1.38 & $(0.45$ to 3.22$)$ \\
\hline 190 & Melanoma of skin & 7 & 5.64 & 1.24 & (0.50 to 2.56$)$ & - & 1.11 & - & - \\
\hline 191 & Skin, other & 18 & 26.57 & 0.68 & (0.40 to 1.07$)$ & 3 & 6.14 & 0.49 & (0.10 to 1.43$)$ \\
\hline 193 & Brain & 8 & 7.26 & 1.10 & (0.47 to 2.17$)$ & 1 & 1.43 & 0.70 & $(0.01$ to 3.89$)$ \\
\hline 196 & Bone & - & 0.45 & - & - & - & 0.08 & - & - \\
\hline 197 & Connective tissue & 2 & 0.93 & 2.15 & $(0.24$ to 7.76$)$ & - & 0.17 & - & - \\
\hline 200,202 & $\begin{array}{l}\text { Non-Hodgkin's } \\
\text { lymphoma }\end{array}$ & 3 & 5.02 & 0.60 & $(0.12$ to 1.75$)$ & 1 & 1.07 & 0.93 & $(0.01$ to 5.20$)$ \\
\hline 201 & Hodgkin's disease & 4 & 2.11 & 1.90 & (0.51 to 4.85$)$ & 1 & 0.35 & 2.86 & (0.04 to 15.90$)$ \\
\hline 204 & Leukaemia & 1 & 5.06 & 0.20 & $(0.00$ to 1.10$)$ & - & 1.14 & - & - \\
\hline
\end{tabular}

* A person may have been employed in more than one work process.

risk of lung cancer with increasing duration of employment, based on a few cases. In a Finnish cohort study, workers in paper mills had a doubled risk of lung cancer with 12 observed cases (SIR 197, 95\% CI 102 to 345). ${ }^{14}$ Smoking could not explain the excess risk of lung cancer among paper mill workers in Finland. ${ }^{24}$ The risk of lung cancer was increased in the pulp and paper industry in proportionate mortality studies, ${ }^{25}{ }^{26}$ and a Canadian case-control study indicated an OR for lung cancer of 1.4 for workers exposed to paper dust. ${ }^{27}$ It has been suggested that exposure to asbestos used as an additive in paper products and in insulation in paper mills may explain the excess risk of lung cancer. ${ }^{28}$ In the Danish paper recycling industry, no asbestos was added to the paper, but asbestos has been used in insulation of pipes in the Danish paper recycling plants. One case of mesothelioma was found among men, which was as expected.

None of the chemicals widely used in the Danish paper recycling industry are known carcinogens, but small amounts of acrylamide may be released in the work environment, ${ }^{9}$ and acrylamide has been evaluated as a probable carcinogen. ${ }^{29}$ Various chlorinated organic compounds may also be released in the work environment, but the amounts are small. ${ }^{2-5}$ Some studies in occupational settings with exposures to chlorophenoxy herbicides and chlorophenols have indicated an excess risk of lung cancer whereas other studies have not. ${ }^{30-33}$

Two studies have shown a reduced risk of lung cancer in workers in cotton textile plants, ${ }^{34}{ }^{35}$ and it has been proposed that endotoxins in the work environment may protect against lung cancer. ${ }^{36}$ This hypothesis was not confirmed in the present study.

Female workers had a doubled risk of colon cancer. Risk of colon cancer was shown to be increased among men in sulphate mills and board mills in Finland, ${ }^{14}$ and in a paper mill in the United States, ${ }^{15}$ as well as in some proportionate mortality studies. ${ }^{37} 38$ As female workers in the Danish paper recycling industry probably had lower exposures than men, the excess risk in women may be due to chance.

Based on only four cases, this study indicated an increased risk of Hodgkin's disease among men working in recycled pulp and paper production. The risk of Hodgkin's disease was increased among employees in paper mills in an American cohort study (SMR $2.33,95 \%$ CI 0.75 to 5.44$)^{16}$ and in proportionate mortality and case-control studies among pulp and paper workers. ${ }^{39-41}$ In a Canadian case-control study, ${ }^{42}$ Hodgkin's disease was significantly increased among men exposed to cellulose, eight cases (OR $4.2,90 \% \mathrm{CI}$ 2.0 to 8.8 ). Cellulose is the major component in paper dust. ${ }^{43}$

In conclusion, this study of the risk of cancer in the Danish paper recycling industry indicated an increased risk of pharyngeal cancer and Hodgkin's disease in men, and to some extent also of lung cancer. However, due to the few cases, the results are only suggestive. Although the cohort included more than 5000 people, the numbers of cancers of specific sites were low as the industry is new and the follow up period short. Furthermore, some misclassification of department of work may have taken place and biased the results. Further evidence of a possible risk of cancer in the paper recycling industry will await a longer follow up of the present cohort and results from other countries. Such studies are needed as paper recycling is now an important industry.

This study was supported from grants No 91-7590 and 93-7627 by the Danish Cancer Society. TS participated in the initial phase of the data collection.

1 International Agency for Research on Cancer. IARC monographs on the evaluation of the carcinogenic risk of chemicals to humans. Wood, leather and some associated industries. IARC, 1981 
2 Vainio $\mathrm{H}$, Hesso A, Jäppinen P. Chlorinated dioxins and dibenzofurans in the environment: a hazard to public health. Scand 7 Work Environ Health 1989;15:377-82.

3 Rappe C. Environmental stable chlorinated contaminants from the pulp and paper industry. In: Vainio $H$, Sorsa $M$ McMichael AJ, eds. Complex mixtures and cancer risk. Lyon International Agency for Research on Cancer, 1990:34153. (IARC Sci Publ vol 104.)

4 Fiedler $\mathrm{H}$, Hutzinger $\mathrm{O}$. Dioxins: sources of environmental load and human exposure. Toxicological and Environmental Chemistry 1990;29:157-234.

5 Klekowski E, Levin DE. Mutagens in a river heavily polluted with paper recycling wastes: results of field and polluted with paper recycling wastes: results of field and laboratory mutage

6 Torén K, Persson B, Wingren G. Health effects of working in pulp and paper mills: malignant diseases. $A m \mathcal{F}$ Ind $M e d$

7 Gupta N, Kennett RL. Recycling and recycled paper. fAMA 1992;267:3333-4.

8 The Danish Ministry of Environment. Economy and paper recycling. Report No 294. Copenhagen: The Danish Ministry of Environment, 1995. (In Danish.)

9 Rix BA, Lynge E. Industrial hygiene measurements in a new industry: the repulping and deinking of paper waste. $A m \mathcal{F}$ Ind Med 1996;30:142-7.

10 Coleman M, Douglas A, Hermon C, Peto J. Cohort study analysis with a Fortran computer program. Int $\mathcal{F}$ Epidemiol 1986;15:134-7.

11 Breslow NE, Day NE. Statistical methods in cancer research. Vol II. Lyon: International Agency for Research on Cancer, 1987.

12 Preston DL, Lubin JH, Pierce DA, McConney ME. Epicure. Seattle: Hirosoft, 1993

13 Robinson CF, Waxweiler RJ, Fowler DP. Mortality among production workers in pulp and paper mills. Scand f Work Environ Health 1986;12:552-60.

14 Jäppinen P, Hakulinen T, Pukkala E, Tola S, Kurppa K Cancer incidence of workers in the Finnish pulp and pape industry. Scand f Work Environ Health 1987;13:197-202.

15 Henneberger PK, Ferris JR BG, Monson RR. Mortality among pulp and paper workers in Berlin, New Hampshire. $\mathrm{Br} \mathcal{F}$ Ind Med 1989;46:658-64.

16 Matanoski G, Kanchanaraksa S, Lantry D. Health profile of long-term workers in the pulp and paper industry. Baltimore: Johns Hopkins University, 1995.

17 International Agency for Research on Cancer. IARC monographs on the evaluation of the carcinogenic risk of chemicals to humans. Tobacco smoking. Lyon: IARC, 1986.

18 International Agency for Research on Cancer. IARC monographs on the evaluation of the carcinogenic risk of chemicals to humans. Alcohol drinking. Lyon: IARC, 1988.

19 Lynge E, Rix BA, Villadsen E, Andersen I, Hink M, Olsen $\mathrm{E}$, et al. Cancer in printing workers in Denmark. Occup Environ Med 1995;52:738-44.

20 Axelson O. Aspects on confounding in occupational health Axelson O. Aspects on confounding in occupational health

21 Schwartz E. A proportionate mortality ratio analysis of pulp and paper mill workers in New Hampshire. Br f Ind Med 1988;45:234-8.

22 Decoufle $\mathrm{P}$, Stanislawczyk K. $A$ retrospective survey of cancer in relation to occupation. Cincinnati: US Department of Health, Education, and Welfare, 1977.

23 Stewart PA, Schairer C, Blair A. Comparison of jobs, exposures, and mortality risks for short-term and long-term workers. Fournal of Occupational Medicine 1990;32:703-8.
24 Jäppinen $\mathrm{P}$, Tola $\mathrm{S}$. Smoking among Finnish pulp and paper workers -evaluation of its confounding effect on lung cancer and coronary heart disease rates. Scand $\mathcal{f}$ Work Environ Health 1986;12:619-26.

25 Menck HR, Henderson BE. Occupational differences in rates of lung cancer. Fournal of Occupational Medicine 1976; 18:797-801.

26 Solet D, Zoloth SR, Sullivan C, Jewett J, Michaels DM. Patterns of mortality in pulp and paper workers. Fournal of Occupational Medicine 1989;31:627-30.

27 Siemiatycki J, Richardson L, Gérin M, Goldberg M, Dewar $\mathrm{R}$, Désy $M$, et al. Association between several sites of cancer and nine organic dusts: results from an hypothesisgenerating case-control study in Montreal 1979-83. Am f Epidemiol 1986;123:235-49.

28 Thoren $\mathrm{K}$, Järvholm $\mathrm{B}$, Hagberg $\mathrm{S}$. Comment on the interpretation of Jäppinen et al concerning increased lung cancer incidence among board mill workers. Scand $\mathcal{f}$ Work cancer incidence among boarc
Environ Health 1988;14:52.

29 International Agency for Research on Cancer. IARC monographs on the evaluation of the carcinogenic risk of chemicals to humans. Some industrial chemicals. Lyon: IARC, 1994.

30 Fingerhut MA, Halperin WE, Marlow DA, Piacitelli LA, Honchar PA, Sweeney MH, et al. Cancer mortality in workers exposed to 2,3,7,8-tetrachlorodibenzo-p-dioxin. $N$ Engl f Med 1991;324:212-8.

31 Becher H, Flesch-Janys D, Kauppinen T, Kogevinas M, Steindorf $\mathrm{K}$, Manz A, Wahrendorf J. Cancer mortality in German male workers exposed to phenoxy herbicides and dioxins. Cancer Causes Control 1996;7:312-21.

32 Saracci R, Kogevinas M, Bertazzi P-A, Bueno de Mesquita BH, Coggon D, Green LM, et al. Cancer mortality in workers exposed to chlorophenoxy herbicides and chlorophenols. Lancet 1991;338:1027-32.

33 Bond GG, Wetterstroem NH, Roush GJ, McLaren EA, Lipps TE, Cook RR. Cause specific mortality among employees engaged in the manufacture, formulation, or packaging of 2,4-dichlorophenoxyacetic acid and related packaging of 2,4-dichlorophenoxyacet
salts. $B r \mathcal{F}$ Ind Med 1988;45:98-105.

34 Levin LI, Gao Y-T, Blot WJ, Zheng W, Fraumeni JF. Decreased risk of lung cancer in the cotton textile industry in Shanghai. Cancer Res 1987;47:5777-81.

35 Henderson V, Enterline PE. An unusual mortality experience in cotton textile workers. Fournal of Occupational Medicine 1973;15:717-9.

36 Enterline PE, Keleti G. Sykora JL, Lange JH. Endotoxins, cotton dust and cancer. Lancet 1985;ii:934-5.

37 Milham S, Demers RY. Mortality among pulp and paper workers. fournal of Occupational Medicine 1984;26:844-6.

38 Solet D, Zoloth SR, Sullivan C, Jewett J, Michaels DM. Patterns of mortality in pulp and paper workers. Fournal of Occupational Medicine 1989;31:627-30.

39 Milham S. Occupational mortality in Washington state 1950-79, US. Cincinnati: US Department of Health and Human Services, 1993.

40 Persson B, Fredriksson M, Olsen K, Boeryd B, Axelson O. Some occupational exposures as risk factors to malignant lymphomas. Cancer 1993;72:1773-8.

41 Milham S, Hesser JE. Hodgkin's disease in woodworkers. Lancet 1967;15:136-7.

42 Siemiatycki J. Risk factors for cancer in the workplace. Boca Raton: CRC Press, 1991

43 Sahle W, Sällsten G, Thorén K. Characterization of airborn dust in a soft paper mill. Ann Occup Hyg 1990;34:55-75. 